\title{
Dampak Fisiologis Kemoterapi Pada Anak dengan Leukemia di Rumah Sakit
}

\section{Sepsi Herfiana ${ }^{1}$, Siti Arifah ${ }^{2 *}$}

1Program Studi Ilmu Keperawatan Universitas Muhammadiyah Surakarta, Kartasura, 57162, Jawa Tengah, Indonesia.

${ }^{2}$ Departemen Keperawatan Anak, Program Studi Ilmu Keperawatan Universitas Muhammadiyah Surakarta, Kartasura, 57162, Jawa Tengah, Indonesia.

*Korespondensi: are_riefah@yahoo.com

\begin{abstract}
Abstrak: Leukemia merupakan salah satu jenis kanker yang cukup sering ditemui pada anak anak. Pengobatan yang tepat untuk leukemia yaitu kemoterapi. Kemoterapi merupakan pengobatan secara sistemik sehingga obat yang diberikan tidak langsung mengenai pada tumor tetapi juga mengenai jaringan normal. Dampak fisiologis ini penting untuk diteliti sebab setiap individu unik sehingga mempunyai dampak fisiologis yang berbeda. Penelitian ini bertujuan untuk mengetahui dampak fisiologis kemoterapi pada anak dengan leukemia. Jenis penelitian ini adalah kuantitatif, metode penelitian deskriptif analitik. Sampel penelitian sebanyak 30 anak dengan teknik total sampling. Instrumen penelitian menggunakan kuesioner dampak fisiologis kemoterapi. Hasil penelitian menunjukan bahwa dampak fisiologis kemoterapi pada anak dengan leukemia yaitu anak yang mengalami alopesia (rambut rontok) sebanyak 24 anak (80\%); mual sebanyak 17 anak (56.7\%), muntah sebanyak 16 anak (53.3\%); penurunan nafsu makan sebanyak 14 anak (46.7\%); sariawan sebanyak 19 anak (63.3\%); diare setelah kemoterapi sebanyak 3 anak (10\%); kelelahan sebanyak 14 anak (46.7\%); peningkatan faktor risiko infeksi yang terdiri dari demam sebanyak 16 anak (53.3\%), batuk sebanyak 13 anak (43.3\%), dan flu sebanyak 8 anak (26.7\%); memar sebanyak 8 anak (26.7\%), perdarahan sebanyak 14 anak (46.7\%); dan efek samping lain sebanyak 14 anak (40\%). Kesimpulan pada penelitian ini yaitu dampak fisiologis yang sering terjadi pada anak yang menjalani kemoterapi yaitu alopesia, sariawan, mual dan muntah, serta demam.
\end{abstract}

Kata kunci : dampak fisiologis, kemoterapi, leukemia, anak.

Abstract: Leukemia is a most common children malignancy. Chemotherapy has been very effective in the management of leukemias. Chemotherapy is a systemic therapy, therefore the chemotherapy drug is not only directly related to the cancer but also damaged the normal tissue. Physiological effect of chemotherapy is important to be inspected because each individual is unique so it has different physiological effect. The aim of this research is to understand physiological effect of chemotherapy in children with leukemia. This research is quantitative research, used descriptive analytic. The sample of this research were 30 respondents by total sampling. The instrument used was a questionnaire of physiological effect of chemotherapy. The results showed that the physiological effect of chemotherapy were children with alopecia of $24(80 \%)$, Nausea of $17(56.7 \%)$, vomiting of 16 children (53.3\%); Decreased appetite of 14 children (46.7\%); oral ulceration of 19 children (63.3\%);Diarrhea of 3 children (10\%); Fatigue of 14 children (46.7\%); increase in risk factors for infection consisting of fever of 16 children (53.3\%), cough of 13 children (43.3\%), and flu of 8 children (26.7\%); Bruises of 8 children (26.7\%), bleeding of 14 children (46.7\%); and other side effects there are 14 children (40\%). The conclusion of this research is the most common physiological effects of children undergoing chemotherapy are alopecia, oral ulceration, nausea and vomiting, and fever.

Keywords: physiological impact, chemotherapy, leukemia, childhood. 


\section{PENDAHULUAN}

Kanker merupakan pertumbuhan sel-sel yang abnormal yang tumbuh secara terus-menerus dan tidak terkendali. Kasus kanker pada anak menjadi penyebab kematian pada anak (Rahmawati, Gamayanti, \& Setyarini, 2016). Salah satunya jenis kanker yang sering dijumpai pada anak adalah leukemia. Berdasarkan data Yayasan Onkologi Anak Indonesia (2012), di seluruh Indonesia terdapat sekitar 11.000 kasus kanker baru pada anak yang ditemukan setiap tahunnya dan $70 \%$ dari kasus tersebut merupakan leukemia atau sekitar 7.700 kasus.

Terapi yang dinilai sangat efektif untuk leukemia adalah kemoterapi. Kemoterapi merupakan pengobatan secara sistemik, oleh karena juga akan merusak jaringan normal. Kerusakan jaringan normal dapat bersifat akut atau kronis. Kebanyakan efek samping akut yang timbul seperti mual, muntah, alopesia, dan penekanan sumsum tulang, sedangkan efek samping lambat yang terjadi berbeda-beda dan termasuk pulmonary fibrosis, neuropathy, dan nephropathy (Salesman, 2017)

Menurut penelitian (Ariawati, Windiastuti, \& Gatgt, 2016) terhadap 41 pasien didapatkan data bahwa terdapat $32 \%$ pasien mengalami neuropati perifer, $14.7 \%$ mengeluh nyeri pada kaki, $2.4 \%$ mengeluh mati rasa dan 51.2\% mengalami demam setelah menjalani kemoterapi. Berdasarkan penelitian (Rahmawaty, Allenidekania, \& Waluyanti, 2014) sebanyak $71.4 \%$ pasien kemoterapi mengeluh kelelahan dan $85.7 \%$ mengeluh mengalami gangguan tidur.

Dampak fisiologis ini penting untuk diteliti sebab setiap individu unik sehingga mempunyai dampak fisiologis yang berbeda oleh karena itu setiap individu akan membutuhkan penanganan yang berbeda.

\section{METODE}

Penelitian ini merupakan penelitian kuantitatif dengan desain penelitian yang digunakan deskriptif analitik. Populasi dalam penelitian ini adalah anak dengan leukemia yang menjalani kemoterapi di Rumah Sakit Umum Daerah Moewardi Surakarta, dari bulan Januari 2016 - Februari 2017 sebanyak 30 anak. Sampel pada penelitian ini diambil dengan menggunakan teknik total sampling yaitu 30 responden. Sampel pada penelitian ini berjumlah 30 anak yang terdiri dari: Pasien leukemia dengan jenis leukemia limfoblastik akut sebanyak 27 anak dan leukemia mieloid akut sebanyak 3 anak. Menjalani kemoterapi lebih dari satu kali, yaitu pada fase induksi sebanyak 11 anak, fase konsolidasi sebanyak 2 anak, dan fase maintenance sebanyak 17 anak.

Peneliti melakukan screening penderita leukemia dengan jenis ALL/AML kemudian peneliti mendatangi pasien satu persatu ke kamar perawatan Setelah bertemu dengan pasien, peneliti memperkenalkan diri dan menyampaikan tujuan bahwa melakukan penelitian tentang dampak fisiologis kemoterapi pada anak dengan leukemia. setelah itu peneliti meminta persetujuan kepada calon responden dengan memberikan informed consent.

Alat ukur yang digunakan dalam penelitian ini adalah kuesioner dampak fisiologis kemoterapi. Analisa data dilakukan dengan menggunakan program SPSS for windows versi 20 dengan uji statistik deskriptif yang meliputi mean dan persentase.

\section{HASIL}

Pasien leukemia yang menjalani kemoterapi distribusi tertinggi berdasarkan jenis kelamin yaitu lakilaki, berdasarkan usia yaitu pada usia 5-10 tahun, dengan jenis ALL dan fase terbanyak pada fase maintenance. 
Tabel 1. Karakteristik Responden

\begin{tabular}{lcc}
\hline \multicolumn{1}{c}{ Karakteristik } & Frekuensi (n) & Persentase (\%) \\
\hline Jenis Kelamin & 22 & \\
Laki-laki & 8 & $73.3 \%$ \\
Perempuan & & $26,7 \%$ \\
Usia Anak & 10 & \\
$1-5$ th & 15 & $33.3 \%$ \\
$5-10$ th & 5 & $50 \%$ \\
$10-15$ th & & $16.7 \%$ \\
Jenis Leukemia & 27 & \\
ALL & 3 & $90 \%$ \\
AML & 11 & $10 \%$ \\
Fase Kemoterapi & 2 & $36.7 \%$ \\
Induksi & 17 & $6.7 \%$ \\
Konsolidasi & & $56.7 \%$ \\
Maintenance & &
\end{tabular}

Tabel 2. Dampak Fisiologi Kemoterapi

\begin{tabular}{lcc}
\hline \multicolumn{1}{c}{ Dampak fisiologis } & Frekuensi (n) & Persentase (\%) \\
\hline Alopecia & 24 & $80 \%$ \\
Mual & 17 & $56.7 \%$ \\
Muntah & 16 & $53.3 \%$ \\
Penurunan nafsu makan & 14 & $46.7 \%$ \\
Sariawan & 19 & $63.3 \%$ \\
Diare & 3 & $10 \%$ \\
Kelelahan & 14 & $46.7 \%$ \\
Demam & 16 & $56.7 \%$ \\
Batuk & 13 & $43.3 \%$ \\
Flu & 8 & $26.7 \%$ \\
Memar & 8 & $26.7 \%$ \\
Perdarahan & 14 & $46.7 \%$ \\
Efek samping lain Pertambahan & 3 & $10 \%$ \\
Berat badan dan Kulit kering & 2 & $6.7 \%$ \\
Perubahan warna urin & 7 & $23.3 \%$ \\
Mati rasa pada kaki dan tangan & 1 & $0.3 \%$ \\
\hline
\end{tabular}

Dari penelitian yang dilakukan peneliti didapatkan bahwa dampak fisiologis kemoterapi pada anak dengan leukemia yang sering dialami oleh anak yaitu alopesia (rambut rontok) (80\%); mual (56.7\%), muntah (53.3\%) dan demam (53.3\%).

\section{PEMBAHASAN}

Penderita leukemia yang menjalani kemoterapi paling banyak adalah laki-laki. Berdasarkan populasi satu tahun terakhir di Rumah Sakit Umum Daerah Dr. Moewardi penderita leukemia yang paling banyak adalah laki-laki. Menurut Isnaini dan Tuntun (2016) yang mengatakan bahwa insiden leukemia lebih tinggi terjadi pada anak laki-laki dibandingkan dengan anak perempuan.

Kejadian pada penelitian ini ditemukan bahwa usia yang paling banyak menjalani kemoterapi pada usia 5-10 tahun, hal ini dikarenakan populasi dalam satu terakhir menunjukkan bahwa usia penderita. Hal ini berbeda dengan Permono, \& Ratwita (2016) yang mengatakan bahwa puncak insiden leukemia terjadi pada anak dengan usia antara 2 sampai 5 tahun. 
Pasien leukemia terbanyak adalah jenis ALL, hal ini dikarenakan leukemia pada anak berbeda dengan leukemia pada dewasa. Pada anak leukemia dengan jenis ALL ditemukan lebih banyak yaitu sekitar 80\% (Pramartasari, 2007)

Pada fase kemoterapi yang dijalani pasien sebagian besar pada fase maintenance, hal ini dikarenakan populasi yang diambil dalam penelitian ini adalah populasi pasien leukemia dalam satu tahun terakhir. Pengobatan utama leukemia adalah kemoterapi. Kemoterapi yang diberikan secara tunggal atau kombinasi dengan pengobatan lain dengan lama pemberian sampai dua-tiga tahun.

\section{Dampak Fisiologis Kemoterapi}

Dalam penelitian didapatkan data bahwa dampak fisiologis kemoterapi pada anak dengan leukemia yang dialami oleh anak yaitu alopesia (rambut rontok), mual, muntah, penurunan nafsu makan, sariawan, diare, kelelahan, demam, batuk, flu, memar, perdarahan, pertambahan berat badan, kulit kering, perubahan warna urin, dan mati rasa pada kaki dan tangan.

Obat kemoterapi bereaksi melawan sel sel yang membelah secara cepat. Hal inilah yang menjadi alasan mengapa obat kemoterapi digunakan untuk melawan sel sel kanker. Namun, ternyata tubuh sendiri memiliki sel sel lain yang juga membelah dengan cepat seperti sel yang berada di sumsum, lapisan mulut, lambung dan usus, serta folikel rambut (Society, 2016)

Kemoterapi merusak sel normal yang berproliferasi dengan cepat termasuk sel folikel rambut, menyebabkan rambut rontok. Rambut rontok disebabkan oleh agen kemoterapi bersifat sementara, mencakup rambut di seluruh tubuh, dimulai 1-2 minggu setelah pemberian kemoterapi dan rambut akan tumbuh dalam 1-2 bulan setelah pengobatan berakhir dengan tekstur dan konsistensi yang agak berbeda daripada rambut sebelumnya (Ambarwati \& Wardani, 2013; Luanpitpong, 2014)

Obat kemoterapi menyebabkan iritasi pada mukosa lambung dan duodenum yang kemudian merangsang pusat muntah di sistem saraf pusat. Kemoterapi juga menyebabkan aktivasi sistem saraf pusat obstruksi, pengosongan lambung terlambat, dan reaksi inflamasi. Obat- obat kemoterapi yang dapat menyebabkan mual dan muntah yaitu Methotrexate, Vincristine, Daunorubicin (Hawkins \& Grunberg, 2009). Penurunan nafsu makan berhubungan dengan mual dan perubahan rasa yang dialami oleh beberapa anak sebagai respons terhadap agen kemoterapi tertentu. Penurunan nafsu makan dapat menyebabkan malnutrisi yang mengakibatkan penurunan berat badan dan mengganggu pertumbuhan (Purnamasari, Widjojo, Antono, \& Syampurnawati, 2012). Meskipun antiemetik dapat efektif dalam mencegah mual dan muntah, namun tidak dapat mencegah perubahan rasa yang diakibatkan oleh pemberian terapi kemoterapi (James, S. R., Nelson, K. A., \& Ashwill, 2013). Penurunan nafsu makan dapat juga disebabkan oleh masalah tenggorokan, terasa tertekan atau kelelahan (Society, 2016).

Pasien dengan kemoterapi mempunyai risiko terkena sariawan sebesar 30-75\%. Sariawan terjadi karena kerusakan pada sel epitel akibat pemberian terapi yang melalui dua cara yaitu secara langsung dan tidak langsung. Secara langsung kemoterapi mengganggu produksi, kematangan dan penggantian sel epitel; sedangkan secara tidak langsung disebabkan karena depresi sumsum tulang akibat pemberian kemoterapi, yang menyebabkan terjadinya neutropenia dan trombositopenia, sehingga terjadi peningkatan risiko perdarahan dan infeksi (Anver \& Manopo, 2017)

Obat kemoterapi menyerang sel epitel mukosa pada usus yang mempunyai sifat yang cepat tumbuh dan jika tidak ada pergantian sel mukosa yang baru, sel ini akan atrofi dan mengalami inflamasi. Mukosa yang terinflamasi akan menghasilkan lendir yang merangsang peristaltik. Hal inilah yang menyebabkan diare. Obat kemoterapi yang menyebabkan diare umumnya metrotexate, hydroxyuera dan dactinomycin (Anver \& Manopo, 2017; Ariawati et al., 2016).

Kelelahan pada pasien kemoterapi disebabkan oleh anemia dan penurunan nafsu makan yang menyebabkan berkurangnya kebutuhan energi. Kemoterapi mengakibatkan terjadinya pelepasan zat sitokin dan interleukin yang merangsang hipotalamus untuk menurunkan rasa lapar yang mengakibatkan terjadinya penurunan nafsu makan sehingga kebutuhan energi dalam tubuh tidak tercukupi (Vitkauskaitè, Juozaitytė, Druktenienė, \& Bunevičius, 2011) 
Kemoterapi menyebabkan aktivitas abnormal dari sistem kekebalan tubuh, sehingga hal ini dapat menyebabkan kelelahan. Sitokin merupakan protein yang dilepaskan oleh sel darah putih dalam merespon infeksi. kanker dan pengobatannya. Dapat mengganggu tingkat sitokin. Sitokin membawa pesan yang berfungsi untuk mengatur sistem imun dan endokrin. Tetapi dalam jumlah yang tinggi dapat berubah menjadi racun dan inflamasi yang dapat menyebabkan kelelahan. Berdasarkan teori, tingkat sitokin yang tinggi akan memperburuk peradangan dan mengganggu produksi dari serotonin (Leukemia, 2016).

Kemoterapi menekan sumsum tulang sehingga produksi sel dalam sumsum tulang menurun, salah satunya adalah trombosit. Trombosit adalah sel-sel yang membantu menghentikan perdarahan dengan mengganti sel darah yang rusak dan membantu sel darah membeku. Jika jumlah trombosit tidak cukup, maka kemungkinan mudah terjadi perdarahan atau memar, bahkan dari cedera ringan (Society, 2016). Trombositopenia terjadi karena adanya penekanan sumsum tulang. Kompartemen penyimpanan pada sumsum tulang dapat mensuplai sel- sel matur ke peredaran darah perifer selama 8 sampai 10 hari. Trombositopenia dapat menyebabkan anak memiliki bintik-bintik kecil pada kulit, muntah darah, perdarahan pada gusi dan hidung (Miller, 2016).

Neuropati perifer meliputi sensorik dan motorik. obat kemoterapi tertentu dapat mempengaruhi otot menjadi lemah, lelah bahkan sakit. Obat kemoterapi yang menyebabkan toksisitas neurologis berupa neuropati pada anak umumnya adalah vincristine (Pertiwi, 2013)

Agen sitotoksik menyebabkan masalah pada barier kulit seperti ruam kulit, kulit kering dan hiperpigmentasi. Gejala pada kulit akan terlihat dalam waktu dua minggu pertama kemoterapi (Fabbrocini et al., 2012). Efek samping kemoterapi tergantung pada tipe dan dosis obat yang diberikan dan lama pengobatan

Peningkatan berat badan merupakan salah satu efek dari pemberian obat kortikosteroid. Penggunaan kortikosteroid mengakibatkan peningkatan nafsu makan dan penumpukan lemak pada tubuh. Selain itu kortikosteroid juga meningkatkan gula darah akibat peningkatan glukoneogenesis hati dan penurunan glukosa oleh jaringan perifer (Amrullah, A., Hardiyanto, T. Dewi, 2017).

Beberapa anak memiliki dampak fisiologis yang sama, hal ini dikarenakan beberapa obat kemoterapi memiliki dampak fisiologis yang sama. Seperti senyawa alkil (Cyclophosphamide), Antimetabolit (Methotrexate, 6-Mercaptopurine), Vincristine, Doxorubicin yang memiliki efek samping yang sama yaitu menekan sumsum tulang, menyebabkan rambut rontok, menekan sistem kekebalan tubuh (Roe, 2011).

\section{PENUTUP}

Sebagian besar anak yang menjalani kemoterapi di Rumah Sakit Umum Daerah Dr. Moewardi mengalami dampak fisiologis seperti alopesia (rambut rontok), sariawan, mual, muntah, demam. Kurang dari separuh anak yang menjalani kemoterapi di Rumah Sakit Umum Daerah Dr. Moewardi mengalami dampak fisiologis seperti penurunan nafsu makan, diare, kelelahan, batuk, flu, memar, mudah terjadi perdarahan, pertambahan berat badan, kulit kering, perubahan warna urin, dan mati rasa pada kaki dan tangan.

Diharapkan para keluarga responden mengenai dampak fisiologis yang terjadi pada anak selama proses pengobatan (kemoterapi) dan memberikan dukungan kepada anak selama kemoterapi. Diharapkan perawat mengembangkan kemampuan caring dan memberikan motivasi dalam menghadapi dampak fisiologis yang dari kemoterapi. Peneliti selanjutnya diharapkan mampu mengembangkan hasil penelitian dengan menambahkan cara mengatasi atau tindakan orang tua terhadap dampak fisiologi dari kemoterapi.

\section{DAFTAR PUSTAKA}

Ambarwati, W. N., \& Wardani, E. K. (2014). Efek Samping Kemoterapi Secara Fisik Pasien Penderita Kanker Serviks. Prosiding Seminar Nasional Keperawatan 97-106. Retrieved from 
https://jurnal.unimus.ac.id/index.php/psn12012010/article/view/1428/1481

Amrullah, A., Hardiyanto, T. Dewi, N. (2017). Gambaran Jenis Diabetes Mellitus Pada Berbagai Kelompok Usia di Kabupaten Kotabaru, Nursing News: Jurnal Ilmiah Keperawatan vol 2 No 2, 365-370.

Anver, G. F., Mantik, M. F. J., \& Manopo, J. I. C. (2016). Gambaran Klinis Diare pada Pasien Anak Leukemia Limfoblastik Akut dengan Kemoterapi. E-Clinic , 5(1). https://doi.org/10.35790/ecl.5.1.2017.14764

Ariawati, K., Windiastuti, E., \& Gatot, D. (2016). Toksisitas Kemoterapi Leukemia Limfoblastik Akut pada Fase Induksi dan Profilaksis Susunan Saraf Pusat dengan Metotreksat 1 gram. Sari Pediatri, 9(4), 252. https://doi.org/10.14238/sp9.4.2007.252-8

Fabbrocini, G., Cameli, N., Romano, M. C., Mariano, M., Panariello, L., Bianca, D., \& Monfrecola, G. (2012). Chemotherapy and skin reactions. Journal of Experimental and Clinical Cancer Research, 31(1), 1. https://doi.org/10.1186/1756-9966-31-50

Hawkins, R., \& Grunberg, S. (2009). Chemotherapy-induced nausea and vomiting: Challenges and opportunities for improved patient outcomes. Clinical Journal of Oncology Nursing, 13(1), 54-64. https://doi.org/10.1188/09.CJON.54-64

Isnaini, S. A., \& Tuntun, M. (2016). Kejadian Anemia Pada Penderita Leukemia Limfoblastik Akut di RSUD Dr. Hi. Abdul Moeloek Provinsi Lampung. Jurnal Analis Kesehatan, 5(1), 522-526.

James, S. R., Nelson, K. A., \& Ashwill, J. W. (2013). Nursing Care of Children Principles \& Practice 4th ed. China: Elsevier Saunders.

Leukemia, L. S. (2016). Cancer Related Fatigue Fact. in a series providing the latest information for patients, caregivers and healthcare professionals.

Miller, R. (2016). Side Effect of Chemo and Radiation. Health Kids.

Permono, B., \& Ratwita, M. (2016). Luaran Pengobatan Fase Induksi Pasien Leukemia Limfoblastik Akut pada Anak di Rumah Sakit Umum Dr. Soetomo Surabaya. Sari Pediatri, 12(2), 128. https://doi.org/10.14238/sp12.2.2010.128-34

Pertiwi, N. M. I. (2013). Potensi Toksisitas Neurologis Vinkristin Pada Tubuh Yang Terjadi Pada Anak Dengan Leukemia Limfositik Akut. Jurnal Kimia, 7(2), 186-194.

Pramartasari, S. (2007). Respon Gangguan Oral Pada Anak Leukemia Limfoblastik Akut Yang Mendapat Kemoterapi. JIK, 02(02).

Purnamasari, D., Widjojo, B. D., Antono, D., \& Syampurnawati, M. (2012). ACE gene polymorphism and atherosclerotic lesion of carotid artery among offsprings of type 2 diabetes mellitus. Acta Medica Indonesiana, 44(2), 128-134. Retrieved from https://www.scopus.com/inward/record.uri?eid=2-s2.084871884782\&partnerID=40\&md5=25c84f5f1d6de623192a48b5cb058351

Rahmawati, E., Gamayanti, I., \& Setyarini, S. (2016). Pocket book of anxiety for parents of children with acute lymphoblastic leukemia. International Journal of Research in Medical Sciences, (January), 14381445. https://doi.org/10.18203/2320-6012.ijrms20161206

Rahmawaty, F., Allenidekania, A., \& Waluyanti, F. T. (2014). Sleep Disturbances and Fatigue in Adolescents with Cancer Receiving Chemotherapy. Makara Journal of Health Research, 18(2), 87-94. https://doi.org/10.7454/msk.v18i2.4073

Roe, H. (2011). Chemotherapy-induced alopecia: Advice and support for hair loss. British Journal of Nursing, 20(10 SUPPL.). https://doi.org/10.12968/bjon.2011.20.sup5.s4

Salesman, F. (2017). CHMK Nursing Scientific Journal Volume 1. No 2 OKTOBER 2017. 1(2), 31-40.

Society, A. C. (2016). Childhood Leukemia. American Cancer Society . Retrieved October 18, 2016, from http://www.cancer.org/

Vitkauskaitė, E., Juozaitytė, E., Druktenienė, J., \& Bunevičius, R. (2011). A systematic review of cancer related fatigue. Journal Oncology Institute, (2), 74-77.

Yayasan Onkologi Anak Indonesia. (2012). 